\title{
Effort Improving Learning Outcomes Using IT-Based Media for Students Class II SD Negeri Wanutunggal Godong District, Grobogan Regency Academic Year 2020/2021
}

\author{
Wina Puspitasari \\ SD Negeri Wanutunggal \\ briggitawina@gmail.com
}

\section{Article History}

ccepted 14/11/2020

approved 21/11/2020

published 26/11/2020

\begin{abstract}
This research was conducted because of the low learning outcomes of class II SD Negeri Wanutunggal. The method that researchers use in this classroom action research. The subjects in this study were students of class II SD Negeri Wanutunggal which consisted of 26 students. Data were collected by researchers through observation, interviews, tests, and documentation. The results showed that: 1) The application of the CTL model can increase the activities of teachers and students. In the results of observations of teacher activity in cycle I, namely 72.52, and increased to 90.32 in cycle II. While the results of observations of student activity in the first cycle were 70.83, and increased to 91.7 in the second cycle. 2) The increase in student learning outcomes can be seen from the average score of students in Indonesian subjects in the first cycle of 72.7 with a percentage of $69.23 \%$, in the second cycle it was 78.4 , with a percentage of $80.8 \%$. In mathematics subjects also experienced an increase, namely in the first cycle of 69.5, with a percentage of $57.7 \%$, in the second cycle it became 77 with a percentage of $80.76 \%$.
\end{abstract}

Keywords: Learning, powerpoint, learning outcomes

\begin{abstract}
Abstrak
Penelitian ini dilakukan karena rendahnya hasil belajar siswa kelas II SD Negeri Wanutunggal. Metode yang peneliti gunakan dalam penelitian tindakan kelas ini. Subjek dalam penelitian ini adalah siswa kelas II SD Negeri Wanutunggal yang berjumlah 26 siswa. Pengumpulan data dilakukan oleh peneliti melalui observasi, wawancara, tes, dan dokumentasi. Hasil penelitian menunjukkan bahwa: 1) Penerapan model CTL dapat meningkatkan aktivitas guru dan siswa. Pada hasil observasi aktivitas guru pada siklus I yaitu 72,52 meningkat menjadi 90,32 pada siklus II. Sedangkan hasil observasi aktivitas siswa pada siklus I sebesar 70,83 meningkat menjadi 91,7 pada siklus II. 2) Peningkatan hasil belajar siswa terlihat dari nilai rata-rata siswa pada mata pelajaran bahasa Indonesia pada siklus I sebesar 72,7 dengan persentase $69,23 \%$, pada siklus II sebesar 78,4 dengan persentase $80,8 \%$. Pada mata pelajaran matematika juga mengalami peningkatan yaitu pada siklus I 69,5 dengan persentase $57,7 \%$, pada siklus II menjadi 77 dengan persentase $80,76 \%$.
\end{abstract}

Kata kunci: Pembelajaran, powerpoint, hasil belajar

Social, Humanities, and Education Studies (SHEs): Conference Series https://jurnal.uns.ac.id/shes

p-ISSN 2620-9284

e-ISSN 2620-9292 


\section{PENDAHULUAN}

Rendahnya hasil belajar siswa merupakan salah satu masalah dalam pembelajaran disekolah. Hasil belajar ini dipengaruhi oleh berbagai faktor, baik faktor internal maupun faktor eksternal. Bloom mengemukakan adanya tiga faktor utama yang mempengaruhi hasil belajar, yaitu kemampuan kognitif, motivasi berprestasi dan kualitas pembelajaran.

Salah satu faktor yang mempengaruhi prestasi siswa adalah motivasi. Dengan adanya motivasi, siswa akan belajar lebih keras, ulet, tekun dan memiliki konsentrasi penuh dalam proses belajar. Dorongan Motivasi dalam belajar merupakan salah satu hal yang perlu dibangkitkan dalam upaya pembelajaran disekolah. Rendahnya motivasi belajar siswa ditunjukkan dengan sikap siswa yang cenderung ingin main hp bersama teman-temannya, tampak jenuh, dan kurang aktif dalam proses pembelajaran, siswa sulit memahami materi yang disampaikan karena guru belum menggunakan media IT berupa PPT dalam pembelajaran berhitung, sebagian siswa enggan bertanya ketika ada penjelasan yang kurang dipahami, dan siswa tidak dapat mengerjakan soal yang diberikan guru dengan benar karena kurang fokus saat mengerjakan, kurang aktif dalam proses pembelajaran, siswa sulit memahami materi yang disampaikan karena guru belum menggunakan media IT berupa PPT dalam pembelajaran berhitung, sebagian siswa enggan bertanya ketika ada penjelasan yang kurang dipahami, dan siswa tidak dapat mengerjakan soal yang diberikan guru dengan benar karena kurang fokus saat mengerjakan.

Motivasi belajar yang rendah tentunya sangat berpengaruh terhadap hasil prestasi belajar. Hasil prestasi belajar siswa kelas II SDN Wanutunggal masih di bawah KKM. Penggunaan media pembelajaran yang praktis dan efektif tentunya dapat meningkatkan prestasi belajar berhitung serta akan mencapai tujuan yang diharapkan. Penggunaan media pembelajaran yang praktis dalam proses belajar mengajar mampu menciptakan suasana belajar yang efektif dan menyenangkan, serta dapat memudahkan siswa dalam menerima dan mengolah informasi yang diterimanya. Selain itu, dapat memberikan kesan pada diri siswa. Siswa akan berupaya untuk merespon dengan berbagai inderanya sehingga informasi tersebut akan lebih mudah dicerna dan disimpan dalam ingatannya. Untuk mengatasi permasalahan pembelajaran yaitu rendahnya prestasi belajar berhitung siswa kelas II SD Negeri Wanutunggal peneliti menetapkan alternatif tindakan dengan menggunakan sebuah media pembelajaran. Model pembelajaran yang digunakan pendidik adalah Contextual Teacher Lerning menjadi 'konduktor' yang ampuh untuk menghantarkan materi pembelajaran dengan metode berbasis IT berupa PPT dan video pembelajaran untuk meningkatkan hasil belajar siswa. Berdasarkan latar belakang masalah tersebut diatas maka peneliti mengidentifikasi masalah dalam penelitian ini sebagai berikut :

1. Kemampuan berhitung siswa kelas 2 masih rendah.

2. Pembelajaran untuk mengembangkan kemampuan berhitung anak kurang berkesan sehingga anak kurang tertarik mengikuti pembelajaran sehingga menyebabkan daya ingat anak terhadap materi pembelajaran belum optimal.

Analisis Masalah, Kemampuan berhitung siswa kelas II SD Negeri Wanutunggal Kecamatan Godong Kabupaten Grobogan belu optimal. 


\section{METODE}

Metode yang peneliti gunakan pada penelitian tindakan kelas ini adalah model kurt lewin yang didalamnya terdapat 4 (empat) tahap yaitu perencanaan, tindakan, observasi, dan refleksi. Subjek pada penelitian ini adalah siswa kelas II SD Negeri Wanutunggal yang terdiri dari 26 siswa. Pengambilan data dilakukan peneliti melalui observasi, wawancara, tes, dan dokumentasi.

\section{HASIL DAN PEMBAHASAN}

PTK merupakan salah satu publikasi ilmiah dalam konteks pengembangan profesi guru secara berkelanjutan yang ditujukan untuk perbaikan dan peningkatan mutu proses dan hasil pembelajaran atau mutu pendidikan pada umumnya. PTK ini cocok dilakukan oleh guru karena prosesnya praktis.

Langkah-langkah Penelitian Tindakan Kelas Menurut Hopkins (1993), penelitian tindakan kelas diawali dengan perencanaan tindakan (Planning), penerapan tindakan (action),mengobservasi dan mengevaluasi proses dan hasil tindakan (Observation and evaluation). Sedangkan prosedur kerja dalam penelitian tindakan kelas terdiri atas empat komponen, yakni perencanaan (planning), pelaksanaan (acting), pengamatan (observing), dan refleksi (reflecting), dan seterusnya hingga perbaikan atau peningkatan yang diharapkan tercapai (kriteria keberhasilan). Lebih singkatnya, langkah-langkah penelitian tindakan kelas diantaranya yaitu:

1. Perencanaan (Planning), yaitu persiapan yang dilakukan untuk pelaksanaan Penelitian Tindakan Kelas.

2. Observasi (Observe). Ini dilakukan untuk melihat pelaksanaan semua rencana yang telah dibuat dengan baik, tidak ada penyimpangan-penyimpangan yang dapat memberikan hasil yang kurang maksimal dalam meningkatkan hasil belajar siswa.

3. Refleksi (Reflecting), yaitu kegiatan evaluasi mengenai perubahan yang terjadi atau hasil yang diperoleh atas yang terhimpun sebagai bentuk dampak tindakan yang sudah dirancang.

Motivasi belajar adalah keseluruhan daya penggerak psikis di dalam diri siswa yang menimbulkan kegiatan belajar, menjamin kelangsungan kegiatan belajar dan memberikan arah pada kegiatan belajar demi mencapai suatu tujuan. Peranannya yang khas adalah sebagai penumbuh gairah, merasa senang dan bersemangat untuk belajar. Dalam hal ini siswa yang memiliki motivasi belajar yang sangat kuat akan memiliki banyak energi dalam belajar, sehingga akan berpengaruh pada prestasi yang akan dicapai.

Media adalah sebuah alat yang mempunyai fungsi menyampaikan pesan. Media pembelajaran adalah sebuah alat yang berfungsi untuk menyampaikan pesan pembelajaran. Pembelajaran adalah sebuah proses komunikasi antara pelajar, pengajar dan bahan ajar. Komunikasi tidak akan berjalan tanpa bantuan sarana penyampai pesan atau media.

Perkembangan ilmu pengetahuan dan teknologi semakin mendorong upayaupaya pembaharuan dalam pemanfaatan hasil-hasil teknologi dalam proses belajar mengajar. Para guru dituntut agar mampu menggunakan alat-alat yang dapat disediakan oleh sekolah, dan tidak tertutup kemungkinan bahwa alat-alat tersebut sesuai dengan perkembangan dan tuntutan zaman. Media adalah bagian yang tidak terpisahkan dari proses belajar mengajar demi tercapainya tujuan pendidikan pada umumnya dan tujuan pembelajaran di sekolah pada khususnya.

Dalam suatu proses belajar mengajar, dua unsur yang sangat penting adalah metode mengajar dan media pengajaran. Kedua aspek ini saling berkaitan. Pemilihan 
salah satu metode mengajar tertentu akan mempengaruhi jenis media pengajaran yang sesuai, fungsi utama media pengajaran adalah sebagai alat bantu mengajar yang turut mempengaruhi iklim, kondisi, dan lingkungan belajar yang ditata dan diciptakan oleh guru.

Hamalik (1986) mengemukakan bahwa pemakaian media pengajaran dalam proses belajar mengajar dapat membangkitkan keinginan dan minat yang baru, membangkitkan motivasi dan rangsangan kegiatan belajar, dan bahkan membawa pengaruh-pengaruh psikologis terhadap siswa.

Secara umum, manfaat media dalam proses pembelajaran adalah memperlancar interaksi antara guru dengan siswa sehingga pembelajaran akan lebih efektif dan efisien. Penyampaian materi pelajaran dapat diseragamkan Proses pembelajaran menjadi lebih jelas dan menarik.

Kemampuan berhitung adalah kemampuan untuk menggunakan penalaran, logika dan angka-angka. Pengertian kemampuan berhitung permulaan adalah kemampuan yang dimiliki setiap anak untuk mengembangkan kemampuannya, karakteristik perkembangannya dimulai dari lingkungan yang terdekat dengan dirinya, sejalan dengan perkembangan kemampuannya anak dapat meningkat ke tahap pengertian mengenai jumlah, yang berhubungan dengan penjumlahan dan pengurangan.

Adapun manfaat pembelajaran berhitung bagi anak antara lain untuk membelajarkan anak berdasarkan konsep dasar matematika yang benar, menarik dan menyenangkan, menghindari ketakutan terhadap pembelajaran berhitung sejak awal dan membantu anak belajar berhitung secara alami melalui kegiatan bermain.

Berhitung merupakan bagian dari matematika, diperlukan untuk menumbuhkembangkan keterampilan berhitung yang sangat diperlukan dalam kehidupan sehari-hari, terutama konsep bilangan yang merupakan juga dasar bagi pengembangan kemampuan matematika maupun kesiapan untuk mengikuti pendidikan dasar (Depdiknas, 2007:1).

Matematika merupakan pembelajaran yang ditujukan untuk menumbuhkan dan mendorong siswa agar memiliki kemampuan berpikir cermat, objektif, kritis, logis, dan analitis. Oleh karena itu, siswa harus memiliki kemampuan berhitung yang baik.

\section{SIMPULAN}

Berdasarkan hasil penelitian dan pembahasan tentang peningkatan hasil belajar berhitung dengan menggunakan media berbasis IT berupa powerpoint dan video pada kelas II SD Negeri Wanutunggal, maka dapat ditarik kesimpulan sebagai berikut:

Penerapan metode pembelajaran berbasis IT pada mata pelajaran tematik tema tugasku sehari-hari dapat dikategorikan baik, terbukti dari peningkatan nilai hasil observasi aktivitas guru yang pada siklus I hanya mencapai 72,52 , sedangkan pada siklus II meningkat menjadi 90,32. Begitu juga dengan nilai hasil observasi peserta didik yang pada siklus I sebesar 70,83 dan meningkat menjadi 91,7 pada siklus II. Serta dapat disimpulkan bahwa guru dan peserta didik mampu menerapkan metode pembelajaran berbasis IT berupa powerpoint dan video.

Metode pembelajaran berbasis IT dapat meningkatkan hasil belajar tematik tema tugasku sehari-hari pada siswa kelas II SD Negeri wanutunggal. Hal tersebut dapat dilihat dari nilai rata-rata siswa Bahasa Indonesia pada kondisi awal yakni sebesar 72,7 dengan prosentasi $69,23 \%$ pada siklus I terjadi peningkatan menjadi 78,4 dengan prosentasi $80,8 \%$ dan pada siklus II. Selain pada mata pelajaran Bahasa Indonesia peningkatan hasil belajar juga terbukti dari mata pelajaran matematika yakni 69,5 pada kondisi awal dengan prosentasi $57,7 \%$ kemudian pada siklus II terjadi peningkatan menjadi 77 dengan prosentase $80,76 \%$.

Berdasarkan hasil penelitian yang telah dilaksanakan dengan menerapkan metode pembelajaran berbasis IT, sebagai saran yaitu Pada proses pembelajaran 
harus ditunjang dengan penggunaan media pembelajaran yang relevan, guru harus lebih kreatif dan inovatif dalam menerapkan beberapa model sehingga siswa lebih semangat dalam mengikuti proses pembelajaran sehingga dapat meningkatkan hasil belajar pada pembelajaran tematik.

\section{DAFTAR PUSTAKA}

Arsyad, Azhar (2007). Media Pembelajaran, Jakarta:Raja Grafindo Persada Elpira, Nira ., Ghufron Anik (2015). Jurnal Inovasi Teknologi Pendidikan Volume 2(1) : 94-104

Hopkins (1993),Panduan Guru penelitian Tindakan Kelas, Jakarta Hamalik, Oemar (1986). Media Pendidikan, Bandung : Alumni Mulyasa

Jayusman, lyus., Gurdjita., dan Shavab, Oka Agus Kurniawan (2017). Jurnal Candrasangkala Vol 3 (1)Sardiman, AM. 1992. Interaksi dan Motivasi Belajar Mengajar: Pedoman bagi Guru dan Calon Guru, Jakarta : Rajawali Pers

Rusmiati (2017). Jurnal IImiah Pendidikan dan Ekonomi Volume 1(1), : 21-36

Srimaya (2017). Jurnal Biotek Volume 5 (1) : 53-68 